\title{
Pengembangan Bahan Ajar Matematika Berbasis Matematika Terapan pada Materi Matriks
}

\author{
Rahma Yuliastuti ${ }^{1}$, Joko Soebagyo ${ }^{2}$ \\ ${ }^{1,2}$ Prodi Pendidikan Matematika, Fakultas Keguruan dan Ilmu Pendidikan, Universitas Muhammadiyah Prof. Dr. HAMKA, \\ Jl. Tanah Merdeka No. 20, Jakarta Timur, Indonesia \\ rahmaay04@gmail.com
}

\begin{abstract}
Learning in SMK has not touched much material that is appropriate to the vocational field. Vocational mathematics, especially on matrix material, has not shown the range of applied mathematics material based on initial observations of electronic books. This results in them not having the ability to meet the requirements because the material provided does not help students make connections with their world. This study aims to realize mathematics teaching materials based on applied mathematics on matrix materials that are valid, practical, and effective. The research method used is the Research and Development (R\&D) ADDIE model with 5 stages. The research was conducted at SMKN 1 South Tangerang. The research instrument includes a material expert and media expert validation sheet, a questionnaire on the practicality of teaching materials by the teacher, and a student response questionnaire to teaching materials. Based on the research, the results of the validation of teaching materials by material experts and media experts with an average percentage of $84.12 \%$ (Very Eligible), teacher responses with a percentage of $88.70 \%$ (Very Good), and student responses to teaching materials with an average percentage average $74.10 \%$ (Good). These findings explain that mathematics teaching materials based on applied mathematics on matrix materials are valid, practical, and effectively used. Validity is assessed by experts with aspects determined by BSNP, practical depending on the teacher's opinion, and effective is determined by student experience with responses to teaching materials.
\end{abstract}

Keywords: Teaching Materials, Applied Mathematics, Matrix, SMK.

\begin{abstract}
Abstrak
Pembelajaran di SMK belum banyak menyentuh materi yang sesuai dengan bidang kejuruan. Matematika SMK khususnya pada materi matriks belum memperlihatkan jangkauan materi matematika terapan berdasarkan pengamatan awal buku sekolah elektronik (BSE). Hal tersebut mengakibatkan mereka belum memiliki kemampuan untuk memenuhi persyaratan karena materi yang diberikan tidak membantu siswa membuat koneksi ke dunia mereka. Tujuannya penelitian untuk mewujudkan bahan ajar matematika berbasis matematika terapan pada materi matriks yang valid, praktis, dan efektif. Metode penelitian yang dipakai yaitu Research and Development (R\&D) model ADDIE dengan 5 tahap. Penelitian dilaksanakan di SMKN 1 Tangerang Selatan. Instrumen penelitian meliputi lembar validasi ahli materi dan ahli media, angket kepraktisan bahan ajar oleh guru, dan angket respon siswa terhadap bahan ajar. Berdasarkan penelitian diperoleh hasil validasi bahan ajar oleh ahli materi dan ahli media dengan ratarata persentase $84,12 \%$ (Sangat Layak), respon guru dengan persentase $88,70 \%$ (Sangat Baik), dan tanggapan siswa terhadap bahan ajar dengan rata-rata persentase $74,10 \%$ (Baik). Hasil temuan menerangkan bahwa bahan ajar matematika berbasis matematika terapan pada materi matriks dikatakan valid, praktis, dan efektif untuk digunakan. Valid dinilai oleh ahli dengan aspek yang ditentukan BSNP, praktis tergantung dari pendapat guru, dan efektif ditetapkan oleh pengalaman siswa dengan respon terhadap bahan ajar tersebut.
\end{abstract}

Kata kunci: Bahan Ajar, Matematika Terapan, Matriks, SMK

Copyright (c) 2021 Rahma Yuliastuti, Joko Soebagyo

$\triangle$ Corresponding author: Rahma Yuliastuti

Email Address: rahmaay04@gmail.com (Jl. Tanah Merdeka No. 20, Jakarta Timur, Indonesia)

Received 02 July 2021, Accepted 12 July 2021, Published 03 August 2021

\section{PENDAHULUAN}

Sekolah Menengah Kejuruan (SMK) yakni jenis lembaga pendidikan formal dimana menyelenggarakan pendidikan kejuruan terusan dari SMP/Mts sederajat untuk mempersiapkan siswa bekerja khususnya di bidang tertentu. Bidang tertentu yang dimaksud adalah bidang yang dipilih dan dipelajari oleh siswa selama berada di lembaga pendidikan kejuruan. SMK merupakan sekolah unik yang berbeda dengan SMA. Perbedaan paling mencolok antara SMA dan SMK terletak pada bagian teori dan 
praktek. Di SMA, teori seringkali lebih penting daripada praktik. Sedangkan di SMK, praktik lebih dari sekadar teori. Kemudian menurut (Effendi, 2017) karena memang kebutuhannya yang berbeda, maka dalam hal pembelajaran khususnya matematika di SMK dan SMA tidak perlu selaras, begitu juga antar bidang keahlian yang satu dengan lainnya.

Pendidikan kejuruan menurut (Billett, 2011) fokus kepada empat tujuan yaitu (1) persiapan untuk masuk dalam dunia kerja juga memberitahukan individu mengenai pilihan pekerjaan mereka; (2) perencanaan awal individu dalam dunia kerja, juga mengembangkan kemampuan untuk melaksanakan pekerjaan yang ditunjuk; (3) pertumbuhan individu yang berkesinambungan dalam dunia kerja sebagai syarat perubahan pekerjaan dari waktu ke waktu; dan (4) ketika seorang individu dipilih atau diharuskan untuk berganti pekerjaan selama bekerja dapat memberikan pengalaman pendidikan yang membantu transisi dari satu pekerjaan ke pekerjaan lain. SMK mempersiapkan siswanya menjadi insan produktif yang dapat bekerja sesuai bidang profesinya setelah menyelesaikan proses pendidikan. Untuk dapat tercapainya tujuan yang tertera, maka tujuan pelajaran di Sekolah Kejuruan, termasuk matematika, perlu diorientasikan dan mengarah pada penguasaan kompetensi keahliannya. Idealnya, pembelajaran di Sekolah Menegah Kejuruan khususnya matematika harus dikembangkan sesuai dengan kebutuhan program keahliannya.

Matematika merupakan ilmu universal atau bersifat umum dan berlaku bagi seluruh orang pada kehidupan sehari-hari. Matematika yaitu salah satu cabang ilmu pengetahuan dan memegang peranan krusial pada kemajuan IPTEK, oleh karena itu dapat digunakan sebagai alat aplikasi bagi disiplin ilmu lain serta perkembangan matematika itu sendiri (Siagian, 2016). Mengingat pentingnya peran matematika, upaya perbaikan sistem pengajaran matematika selalu menjadi perhatian masyarakat, terutama bagi pemerintah dan pakar pendidikan matematika. Perbaikan kurikulum matematika dapat dilihat sebagai salah satu upaya nyata yang dilaksanakan pemerintah.

Kurikulum matematika SMK hanya terdiri dari seperangkat materi dan kegiatan yang tidak fokus pada apa yang dibutuhkan, tidak konsisten dan sukar diterapkan secara vertikal maupun horizontal di dalam kelas (Beane, 1997 \& NCTM, 2000), serta jauh dari pembelajaran bermakna (Effendi, 2017). Hal ini berimbang dengan Permendiknas No. 16 tahun 2007 dan Perdirjen 464/D.D5/KR/2018 bahwa pembelajaran matematika di SMK masih bersifat umum juga teoritis khususnya bidang keahlian teknologi dan rekayasa, walaupun pada beberapa kompetensi dasar mengandung istilah kontekstual.

Pembelajaran matematika di SMK kelompok teknologi dan rekayasa, idealnya, pembelajaran matematika yang mengintegrasikan secara langsung kompetensi jurusannya dan mengakomodir pengetahuan dan kompetensi tentang matematika terapan yang sesuai yang mencakup aspek-aspek keluasan, kedalam, keterkaitan dan berkelanjutan (Hine, 2015). Sebagai gambaran supaya kiat pembelajaran matematika di SMK jurusan listrik menjadi lebih kontekstual, dapat dipahami serta sesuai dengan tantangan kompetensi yang dibutuhkan saat ini, idealnya yaitu memadukan ilmu matematika dan ilmu listrik. Oleh karena itu sangat dibutuhkan konten materi ajar matematika SMK bidang keahlian dan rekayasa yang beririsan dengan jurusannya serta aplikatif.

Seperti yang kita ketahui bahwa matematika terapan adalah implementasi dari konsep, ide dan 
gagasan matematika dalam berbagai bidang di mana literatur matematika mempunyai keluasan, kedalaman, relevansi dan berkelanjutan (Hine, 2015). Suatu konsep matematika apabila diterapkan dalam konteks maka akan jadi bermakna. Menghubungkan matematika dengan suatu konteks bidang kejuruan merupakan masalah matematika terapan (Fatimah \& Zakiah, 2018).

Pedagogi terbaik untuk mengajarkan matematika kepada siswa yang diyakini oleh beberapa matematikawan dan profesional yaitu dengan memperkenalkan dan memakai konsep-konsep matematika diberbagai bidang (Hassani, 2009). Namun, seringkali pengetahuan guru terbatas pada aplikasi umum dari prinsip dan konsep matematika (Gallagher, 2000). Faktanya, bidang teknik memerlukan matematika sebagai alat untuk melakukan tugas-tugasnya (Pahl \& Damrath, 2001).

Pengetahuan tentang aplikasi matematika di berbagai bidang, khususnya bidang teknik terkait erat dengan literasi matematika. Penelitian (Soebagyo \& Purnama, 2019) menunjukkan bahwa terdapat aplikasi matematika yang sesuai dengan matematika sekolah menengah kejuruan yang dapat digunakan guru matematika khususnya di sekolah menengah kejuruan. Sumber penelitian ini menggunakan mesin pencarian Google Book dan Library Genesis untuk mengidentifikasi buku-buku aplikasi matematika dari berbagai bidang, khususnya bidang keteknikan. Oleh karena itu peneliti merekomendasikan supaya para akademisi matematika dan pendidikan matematika memiliki tanggung jawab dalam pembuatan buku ajar matematika terapan, sehingga materi matematika tidak terasa asing dan diharapkan dapat menghilangkan gap antara matematika dan bidang kejuruan di sekolah menengah kejuruan.

Sementara itu, sudah menjadi pengetahuan umum di sekolah menengah kejuruan (SMK) bahwa mayoritas guru dan siswa belum mengetahui aplikasi matematika dalam bidang teknik. Hal tersebut dikarenakan mereka memiliki sedikit pengetahuan tentang aplikasi matematika. Seringkali pengetahuan yang jarang ini terbatas pada aplikasi umum dari prinsip dan konsep matematika. Oleh karena itu, guru tidak dapat membantu siswa membuat koneksi ke dunia mereka, yang merupakan bagian penting dari pemahaman matematika (Gallagher, 2000). Hal ini searah dengan pandangan (Pusdiknakes, 2010) dalam (Effendi, 2017) yang mengutarakan bahwa pelajaran di SMK belum banyak menyinggung atau menumbuhkan kemampuan adaptasi siswa. Mereka belum memiliki kompetensi yang sinkron dengan tuntutan dunia kerja sebagai akibatnya di Indonesia lulusan SMK sebagian besar tidak mampu masuk di lapangan kerja.

Matematika SMK khususnya pada materi matriks belum memperlihatkan jangkauan materi matematika terapan berdasarkan pengamatan awal buku sekolah elektronik (BSE). Bahan ajar yang tersaji lebih mencakup tata cara yang membutuhkan basis pengetahuan untuk diaplikasikan di dunia praktis (Ojose, 2011). Isi pada BSE matematika seperti soal yang tersedia untuk menyelesaikan permasalahan matriks yaitu mengenai determinan dan invers lebih kepada berupa angka-angka. Walaupun terdapat soal cerita tetapi hal itu kurang menghubungkan matematika dengan suatu konteks bidang kejuruan. Hal ini serupa dengan wawancara pada guru matematika SMKN 1 Tangerang Selatan yang mengatakan bahwa bahan ajar yang dipakai untuk materi matriks masih minim materi dan soal yang berkaitan dengan jurusannya yaitu teknik instalasi tenaga listrik. 
Menurut Masduki dan Buchori (2014) dalam (Nurafni, Pujiastuti, \& Mutaqin, 2020) mengemukakan bahwa buku yang disediakan pemerintah masih digunakan oleh beberapa guru di SMK yang mengajar matematika tanpa mencermati isi dan pendekatan yang ada. Hal itu tidak bagus karena jika guru tidak berimprovisasi dan mengembangkan proses pembelajaran, siswa dapat kehilangan minat pada matematika dan pembelajaran mereka mungkin tidak efektif. Kemudian berdasarkan penelitian yang dilakukan oleh (Hasanah, Wirawati, \& Sari, 2020), untuk membuat siswa SMK memahami matematika dengan baik dan mengembangkan diri pada hard skill dan soft skill supaya mereka mampu menyelesaikan masalah yang terjadi pada dunia nyata, maka dilakukan Pengembangan Bahan Ajar Matematika Berbasis STEM Pada Materi Bangun Ruang.

Berdasarkan penelitian - penelitian sebelumnya, untuk membantu siswa dalam belajar maka dibutuhkan ketersedian bahan ajar yang baik juga sinkron pada kebutuhan. Valid, praktis, dan efektif adalah kualitas bahan ajar yang baik dimana dapat mengakomodir kebutuhan siswa, dapat digunakan dengan mudah, dan tentunya meningkatkan hasil belajar siswa.

Ditegaskan dalam PP Nomor 19 tahun 2005, guru dinantikan mengembangkan bahan ajar (Hasanah et al., 2020). Menurut Dikmenjur (Bimtek KTSP, 2009) dalam (Fitrah, 2016), bahan ajar ialah kumpulan materi atau substansi pembelajaran dilapis secara terstruktur, memperlihatkan gambaran lengkap tentang kemampuan yang akan dikuasai siswa pada suatu aktivitas pembelajaran. Artinya, penerapan bahan ajar yang dikembangkan oleh guru diharapkan dapat diperoleh suatu alternatif metode penyampaian bahan ajar, sehingga membuat proses pengajaran lebih optimal dan bervariasi, dan pada akhirnya output belajar juga kegiatan siswa diharapkan akan meningkat. Jika seorang guru mengembangkan bahan ajar sendiri, baik guru maupun siswa akan merasakan banyak manfaat. Hal ini sejalan dengan pendapat Depdiknas (2008; 9) dalam (Noer, 2018) yang mengatakan bahwa manfaat penulisan bahan ajar dibagi jadi dua kategori, diantaranya manfaat untuk guru dan juga siswa. Manfaat untuk guru, diantaranya: memperoleh bahan ajar selaras tuntunan kurikulum serta kebutuhan siswa, meningkatkan wawasan karena berbagai bahan referensi, dan tidak mengandalkan buku teks yang ada kalanya sukar didapat. Sedangkan manfaat untuk siswa, diantaranya: aktivitas pembelajaran lebih menarik, siswa akan mendapatkan kesempatan belajar yang lebih mandiri di bawah bimbingan guru, dan siswa merasa nyaman untuk mempelajari setiap kompetensi yang harus dikuasai.

Hal terpenting dalam mengembangkan bahan ajar yaitu memperhatikan tingkat penalaran siswa. Sebagian besar siswa masih berpikir secara konkrit, terutama pada tingkat SMK. Salah satu kesulitan yang dihadapi siswa ketika belajar matematika adalah sejauh mana materi matematika yang mereka alami berbeda dengan kehidupan nyata yang mereka jalani (Mayani \& Rizki, 2016).

Ketersediaan bahan ajar materi matematika terapan dalam proses pembelajaran menjadi kebutuhan yang mendesak harus dipenuhi supaya pembelajaran menjadi lebih kontekstual, mudah dipahami dan sesuai dengan tantangan kompetensi yang dibutuhkan saat ini. Namun, di SMK belum tersedia dengan baik. Dengan demikian, diperlukan bahan ajar matematika berbasis matematika terapan bagi SMK yang memenuhi konten materi ajar matematika dan beririsan dengan jurusannya serta aplikatif. Adapun materi 
yang bisa dipakai pada kehidupan sehari - hari dan beririsan dengan bidang di SMK khususnya kelompok teknologi dan rekayasa, salah satunya yaitu materi matriks.

Berdasarkan uraian di atas, dalam rangka penyempurnaan bahan ajar pada pelajaran matematika SMK khususnya kelompok teknologi dan rekayasa, maka peneliti merumuskan judul penelitiannya adalah "Pengembangan Bahan Ajar Matematika Berbasis Matematika Terapan pada Materi Matriks".

\section{METODE}

Jenis penelitian yang dipakai yaitu metode penelitian dan pengembangan (R\&D). Mengikuti (Sugiyono, 2019) dalam (Hasanah et al., 2020) mengutarakan bahwa metode penelitian dan pengembangan dipahami bak metode ilmiah untuk meneliti, merancang, melahirkan juga membuktikan efektivitas produk yang dibuat. Untuk itu, tujuan penelitian yaitu membuat suatu produk berupa bahan ajar matematika berbasis matematika terapan yang valid, praktis, dan efektif buat siswa SMK teknik instalasi tenaga listrik pada materi matriks.

Model pengembangan yang dipakai yaitu salah satu model desain pembelajaran sistematika yang dikembangkan oleh Dick dan Carry yaitu model ADDIE dimana terdapat lima tahap. Adapun tahap pengembangan model ADDIE dapat diamati pada gambar dibawah ini (Tegeh, Jampel, \& Pudjawan, 2014).

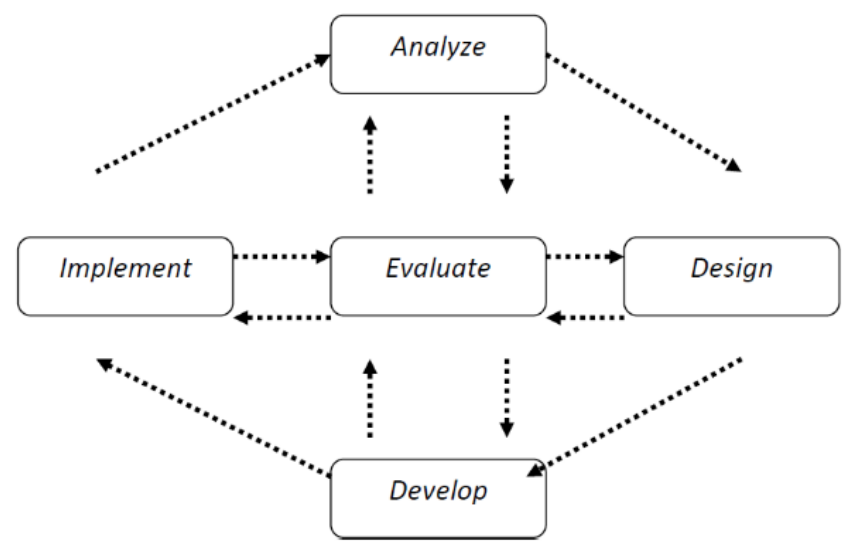

Gambar 1. Tahapan ADDIE Model (Sumber: Anglada, 2007)

\section{Tahap Analisis (Analyze)}

Analisi kebutuhan dijalankan untuk tahap ini yang melingkupi : analisis kurikulum dan analisis karakteristik siswa SMK. Hal ini bertujuan untuk menyesuaikan keperluann yang dibutuhkan di lapangan agar sinkron dan tepat sasaran.

\section{Tahap Perancangan (Design)}

Dalam tahap perancangan difokuskan pada penyusunan materi sejalan dengan analisis yang telah dilakukan. Fase ini dimaksudkan untuk mempersiapkan desain bahan ajar dan memperhatikan format sejak awal hingga akhir.

\section{Tahap Pengembangan (Development)}

Tahap ini dasarnya yaitu kegiatan mentransformasikan spesifikasi desain sehingga diperoleh 
prototipe produk pengembangan. Prototipe bahan ajar yang dikembangkan dinilai para ahli untuk memastikan apakah prototipe ini layak untuk diuji. Selanjutnya, prototipe ini dimodifikasi mengikuti komentar dan saran yang diberikan. Tahap ini tujuannya yaitu menghasilkan draft revisi bahan ajar berdasarkan pendapat para ahli, kemudian nantinya bisa diujicobakan.

\section{Tahap Implementasi (Implementation)}

Pada tahap ini peneliti menggunakan hasil validasi dari para ahli guna memperbaiki atau menyempurnakan bahan ajar awal yang dihasilkan, sehingga lebih tepat sasaran dan memenuhi standar kebutuhan guru dan siswa pada aktivitas pembelajaran. Langkah selanjutnya bahan ajar diujicobakan kepada guru dan siswa SMK.

\section{Tahap Evaluasi (Evaluation)}

Tahap penilaian bahan ajar dipandang dari validasi para ahli, angket kepraktisan penggunaan bahan ajar, dan angket respon siswa untuk melihat kualitas bahan ajar yang dikembangkan. Data pengisian angket berupa angka mengarah pada metode pengisian skala Likert melalui 5 pilihan yaitu : (5) Sangat Baik/Setuju, (4) Baik/Setuju, (3) Cukup Baik/Setuju, (2) Kurang Baik/Setuju, dan (1) Sangat Kurang Baik/Setuju. Konversi Tingkat Pencapaian dengan skala 5 dipantau pada Tabel dibawah ini.

Tabel 1. Konversi Tingkat Pencapaian Skor Ahli

\begin{tabular}{|c|c|}
\hline Tingkat Pencapaian & Kriteria \\
\hline $80 \%<p \leq 100 \%$ & Sangat Layak (SL) \\
\hline $60 \%<p \leq 80 \%$ & Layak (L) \\
\hline $40 \%<p \leq 60 \%$ & Cukup Layak (CL) \\
\hline $20 \%<p \leq 40 \%$ & Tidak Layak (TL) \\
\hline $0 \%<p \leq 20 \%$ & Sangat Tidak Layak (STL) \\
\hline
\end{tabular}

Tabel 2. Konversi Tingkat Pencapaian Hasil Angket

\begin{tabular}{|c|c|}
\hline Tingkat Pencapaian & Kriteria \\
\hline $80 \%<p \leq 100 \%$ & Sangat Baik (SB) \\
\hline $60 \%<p \leq 80 \%$ & Baik (B) \\
\hline $40 \%<p \leq 60 \%$ & Cukup Baik (CB) \\
\hline $20 \%<p \leq 40 \%$ & Tidak Baik (TB) \\
\hline $0 \%<p \leq 20 \%$ & Sangat Tidak Baik (STB) \\
\hline
\end{tabular}

Instrumen dalam penelitian ini menggunakan angket. Angket tersebut meliputi lembar validasi ahli materi dan ahli media, angket kepraktisan penggunaan bahan ajar oleh guru, dan angket respon siswa terhadap bahan ajar. Validator ahli melibatkan 2 dosen pendidikan matematika UHAMKA dan 2 guru matematika SMKN 1 Tangerang Selatan. Sedangkan untuk respon siswa sebagai uji coba merupakan siswa SMKN 1 Tangerang Selatan kelas $\mathrm{X}$ dengan jurusan teknik instalasi tenaga listrik. Dalam penelitian ini, hasil penilaian ahli digunakan untuk mengutarakan bahwa bahan ajar yang dipakai layak dengan atau tanpa revisi, kemudian hasil angket penilaian oleh guru dipakai guna mengetahui respon guru pada bahan ajar meliputi kepraktisan bahan ajar, sedangkan hasil angket respon siswa dipakai guna menunjukkan keefektifan dan kemenarikan bahan ajar.

Jenis data yang digunakan diklasifikasikan menurut sifatnya ada dua. Pertama, data kualitatif berasal 
dari komentar serta saran para validator ahli. Kedua, data kuantitatif berasal dari angket data hasil validasi dari para validator, angket kepraktisan guru dan angket respon siswa.

Analisis data penelitian memakai analisis deskriptif kuantitatif guna mengolah data yang didapat melalui angket dalam wujud deskriptif persentase. Berikut ini adalah rumus yang dipakai menghitung persentase dari masing-masing subjek :

$$
\mathrm{P}=\frac{\sum x}{\sum x_{i}} \times 100 \%
$$

Keterangan :

$$
\begin{array}{ccc}
\mathrm{p} & = & \text { persentase } \\
\sum \mathrm{x} & = & \text { Jumlah nilai jawaban responden pada satu item } \\
\sum \mathrm{x}_{\mathrm{i}} & = & \text { Jumlah nilai ideal pada item }
\end{array}
$$

\section{HASIL DAN DISKUSI}

Penelitian ini menghasilkan bahan ajar matematika berbasis matematika terapan pada materi matriks yang valid, praktis, dan efektif. Bahan ajar ini dirancang bagi siswa SMK jurusan teknik instalasi tenaga listrik sehingga materi dalam pembelajaran matematika beririsan dengan jurusannya. Proses pengembangan bahan ajar ini memakai tahapan ADDIE dengan prosedur yang dilakukan melalui 5 tahapan. Adapun hasil penelitian ini dideskripsikan dalam tahap pengembangan sebagai berikut.

\section{Analisis (Analyze)}

Tahap pertama yaitu analisis dengan hasil yang didapat pada tahap ini dipilih sebagai pedoman untuk penyusunan bahan ajar. Hal yang dilakukan analisis kebutuhan meliputi :

\section{Analisis Kurikulum}

Saat ini pembelajaran di SMK Negeri 1 Tangerang Selatan mengacu pada kurikulum 2013 revisi. Analisis kurikulum yang dilaksanakan yaitu dengan menetapkan materi dan Kompetensi Dasar (KD) dari kurikulum yang berlaku.

\section{Analisis Karakteristik Siswa}

Selama proses pembelajaran era covid19 ini, siswa SMKN 1 Tangerang Selatan melakukan kegiatan pembelajaran dengan metode daring, dimana guru memberikan bahan ajar berupa modul atau video pembelajaran setiap 2 minggu sekali melalui platform sekolah dan dipelajari secara mandiri. Kemudian untuk tugas atau latihan soal pada bahan ajar dikumpulkan pada akhir semester. Bahan ajar yang dipakai masih minim materi yang dikaitkan dengan bidang kejuruannya yaitu teknik instalasi tenaga listrik.

\section{Perancangan (Design)}

Dalam tahap perancangan difokuskan pada desain bahan ajar sejalan dengan tahap pertama yang telah dilaksanakan. Kegiatan perancangan dalam penelitian yaitu: 


\section{Menyusun Materi}

Menyusun materi guna untuk menunjukkan bahan ajar ini berbasis matematika terapan yaitu terdapat pada penjelasan materi, contoh dan latihan soal. Menyusun materi untuk kebutuhan pengembangan bahan ajar berbasis matematika terapan pada materi matriks yaitu dengan mencari informasi mengenai pokok bahasan pada materi matriks menggunakan referensi buku matematika sekolah dan modul pada internet. Sedangkan untuk materi dan soal - soal mengenai matematika terapan pada materi matriks diperoleh berdasarkan hasil analisis buku dan jurnal serta website.

\section{Menetapkan Struktur Bahan Ajar}

Dalam tahap design difokuskan pada penyusunan materi sesuai dengan analisis yang telah dilakukan. Kerangka atau struktur bahan ajar dibuat dalam bentuk poin-poin isi bahan ajar sebagai berikut: cover dan judul, kata pengantar, daftar isi, glosarium, peta konsep, pendahuluan, kegiatan pembelajaran, kunci jawaban, dan daftar pustaka.

\section{Pembuatan Instrumen Penelitian}

Instrumen yang dibuat untuk memenuhi kebutuhan penelitian meliputi lembar penilaian bahan ajar, angket kepraktisan penggunaan bahan ajar oleh guru, dan angket respon siswa terhadap bahan ajar. Penyusunan instrumen lembar validasi untuk bahan ajar mengikuti Badan Standar Nasional Pendidikan (BSNP). Penilaian ahli materi mencakup aspek kelayakan isi, penyajian dan kebahasaan. Sementara itu, penilaian untuk ahli media mencakup aspek kelayakan kegrafikan.

\section{Pengembangan (Development)}

Prototipe bahan ajar yang sudah dikembangkan, kemudian divalidasi oleh para ahli. Validasi yang dilaksanakan validator adalah untuk mengevaluasi semua aspek yang ditanyakan pada lembar validasi. Lalu lembar validasi juga disediakan komentar juga saran buat perbaikan bahan ajar. Di akhir lembar validasi, validator memberikan kesimpulan tentang kelayakan bahan ajar secara umum buat diujicobakan. Penilaian data kuantitatif berupa skor instrumen angket validasi oleh ahli materi disediakan pada Tabel 3.

Tabel 3. Hasil Penilaian Kuantitatif Ahli Materi

\begin{tabular}{|c|c|c|c|c|c|}
\hline \multirow{2}{*}{ No } & \multirow{2}{*}{ Aspek } & \multicolumn{2}{|c|}{ Validator } & \multirow{2}{*}{$\begin{array}{c}\text { Skor } \\
\text { Rata - rata }\end{array}$} & \multirow{2}{*}{ Kategori } \\
\hline & & 1 & 2 & & \\
\hline 1 & Kelayakan Isi & $89,34 \%$ & $81,34 \%$ & $85,34 \%$ & Sangat Layak \\
\hline 2 & Kelayakan Penyajian & $85,45 \%$ & $72,73 \%$ & $79,09 \%$ & Layak \\
\hline 3 & Kelayakan Kebahasaan & $86,67 \%$ & $68,69 \%$ & $77,78 \%$ & Layak \\
\hline \multicolumn{4}{|c|}{ Total } & $80.74 \%$ & Sangat Layak \\
\hline
\end{tabular}

Selanjutnya yaitu penilaian data kuantitatif ahli media. Berikut hasil penilaian data kuantitatif berupa skor instrumen angket validasi oleh ahli media disediakan pada Tabel 4.

Tabel 4. Hasil Penilaian Kuantitatif Ahli Media

\begin{tabular}{|c|c|c|c|c|c|}
\hline \multirow{2}{*}{ No } & \multirow{2}{*}{ Aspek } & \multicolumn{2}{|c|}{ Validator } & \multirow{2}{*}{$\begin{array}{c}\text { Skor } \\
\text { Rata }- \text { rata }\end{array}$} & \multirow{2}{*}{ Kategori } \\
\cline { 3 - 6 } & & 1 & 2 & $85,00 \%$ & Sangat Layak \\
\hline 1 & Ukuran Bahan Ajar & $80,00 \%$ & $90,00 \%$ & $87,15 \%$ & Sangat Layak \\
\hline 2 & Desain Sampul Bahan Ajar & $74,29 \%$ & $100,00 \%$ & 8 & \\
\hline
\end{tabular}




\begin{tabular}{|c|c|c|c|c|c|}
\hline 3 & Desain Isi Bahan Ajar & $81,12 \%$ & $100,00 \%$ & $90,26 \%$ & Sangat Layak \\
\hline \multicolumn{3}{|c|}{ Total } & $\mathbf{8 7 . 7 4 \%}$ & Sangat Layak \\
\hline
\end{tabular}

Hasil skor penilaian validasi bahan ajar oleh validator dapat diakumulasikan menjadi rata-rata skor keseluruhan untuk memastikan kelayakan prototipe I bahan ajar. Berikut rata - rata skor penilaian kuantitatif oleh para validator disediakan pada Tabel 5.

Tabel 5. Hasil Skor Rata - rata Penilaian Kuantitatif Para Validator

\begin{tabular}{|c|c|c|c|c|}
\hline No & Validator & Total Skor Rata - Rata & Persentase Keseluruhan & Kategori \\
\hline 1 & Ahli Materi & $80,74 \%$ & $\mathbf{8 4 , 1 2 \%}$ & Sangat Layak \\
\hline 2 & Ahli Media & $87,74 \%$ & & \\
\hline
\end{tabular}

Berdasarkan Tabel 5. dapat diperhatikan prototipe I bahan ajar matematika berbasis matematika terapan pada materi matriks menunjukkan hasil penilaian ahli materi dengan persentase $80,74 \%$ dan untuk hasil penilaian ahli media dengan persentase $87,47 \%$. Dari kedua hasil itu diperoleh skor rata - rata penilaian kuantitatif para validator dengan persentase $84,12 \%$ yang artinya bahan ajar matematika berbasis matematika terapan pada materi matriks Layak digunakan. Setelah dilakukan validasi, selanjutnya melaksanakan revisi produk dari komentar/saran para ahli. Berikut hasil revisi disediakan pada Tabel berikut.

Tabel 6. Hasil Revisi Bahan Ajar dari Ahli Materi

\section{Produk I}

Produk II (Final)

Modul bisa ditambahkan tingkat penguasaan yang dicapai oleh siswa pada setiap kegiatan. Mulai dari kurang, cukup, baik, dan baik sekali.

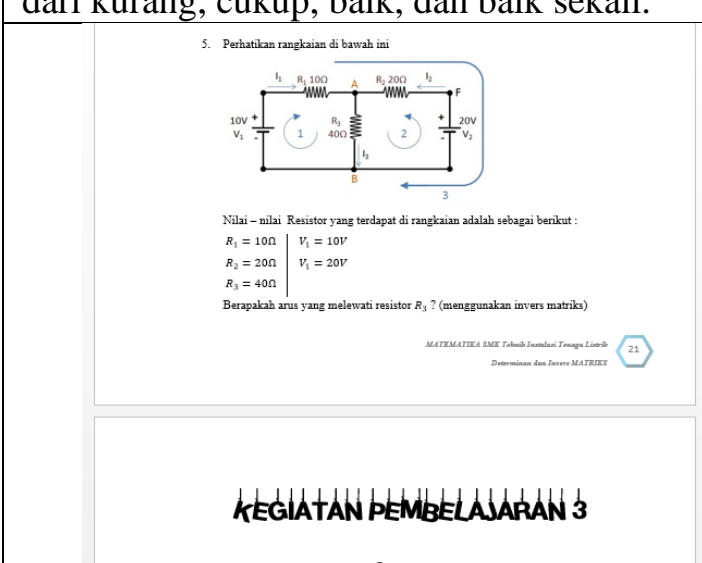

Determinar Matriks OKDo $3 \times 3$

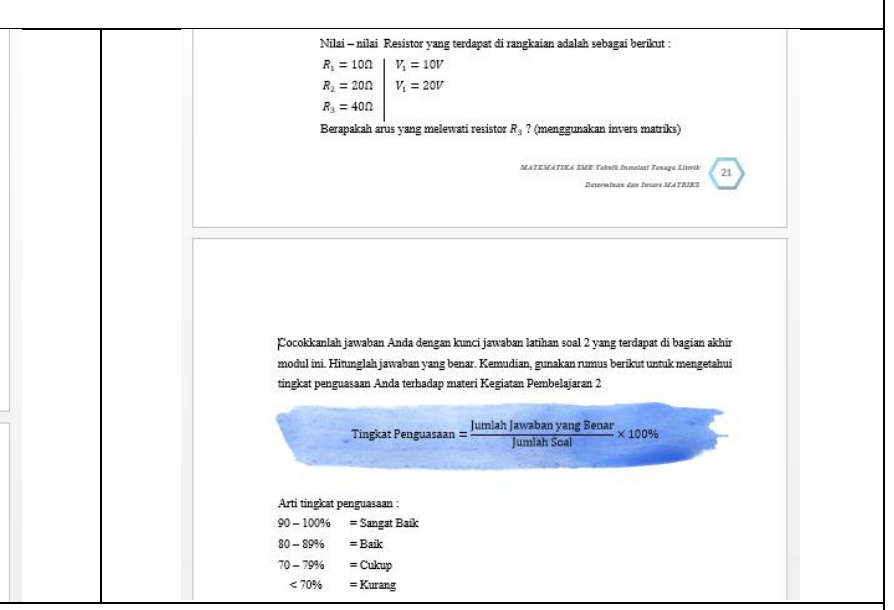

$<70 \% \quad=$ Kurar

Modul bisa dibuat agar lebih menarik lagi dengan menambahkan warna, shape, atau desain tampilan yang sesuai dengan usia siswa SMK. 


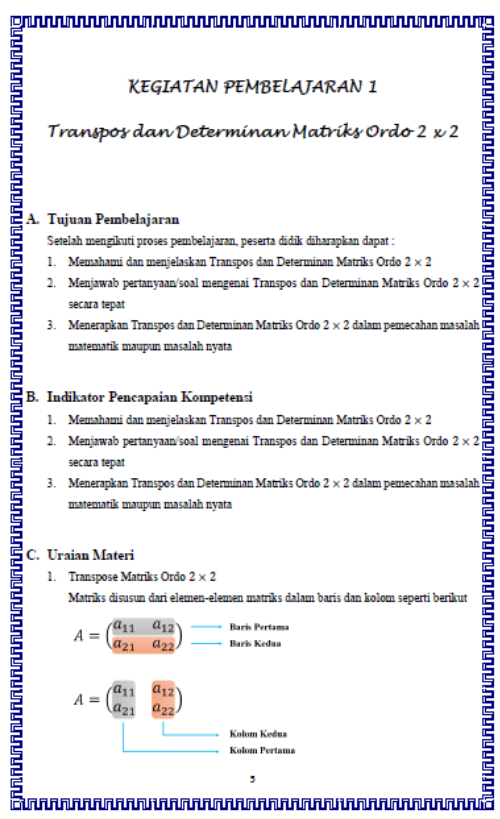

\section{KEGIATAN PEMBBELLSARAN 1}

Transpos Dak DETERMinar Maturs OxDo $2 \times 2$

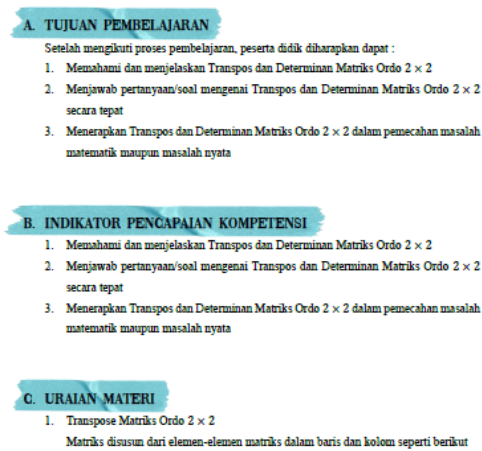

Marniks disusuru dari elemen-

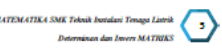

Langkah-langkah pembahasan dalam contoh soal, alangkah baiknya tidak di beri jawaban semuanya, alangkah baiknya hanya berupa perintah supaya siswa lebih mandiri dalam pengerjaan soal dan rasa ingin tahu siswa lebih tinggi.
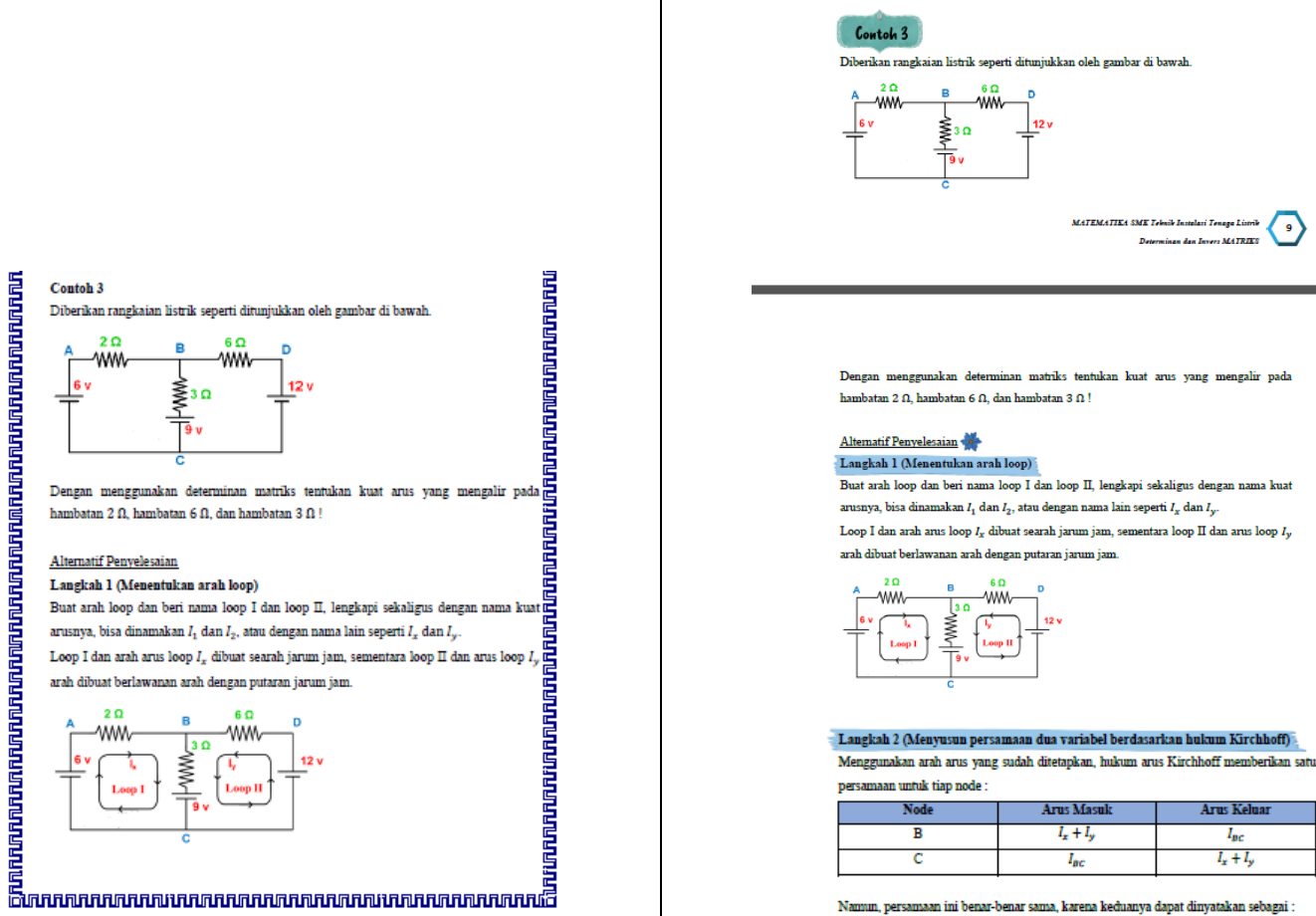

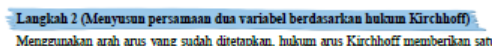
Menggumakan arah ans yale
persamanan wruls tiap node:

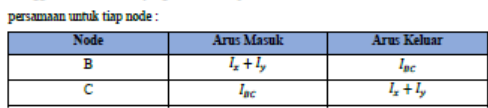

Nammin, persamesn ini benas-benar sema, karena kedunya dapat dinyatakan sebagai $I_{x}+L_{y}=I_{p c}$

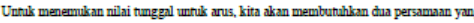
akan kit perolet dari hulum tegangan Kirchhoff

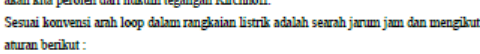

1. Peecurnann tegangan terjadi pada resistor jika arah yang ditetapkan ke anus melaluid resistor sama dengan anh yang dititapkan ke loop, dan kenalisan tegangan terjadi pada resistor jika anh yang ditetengkan ke arus melahui resistor berlawwanan dengan arah yang ditetapkan ke loop.

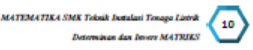



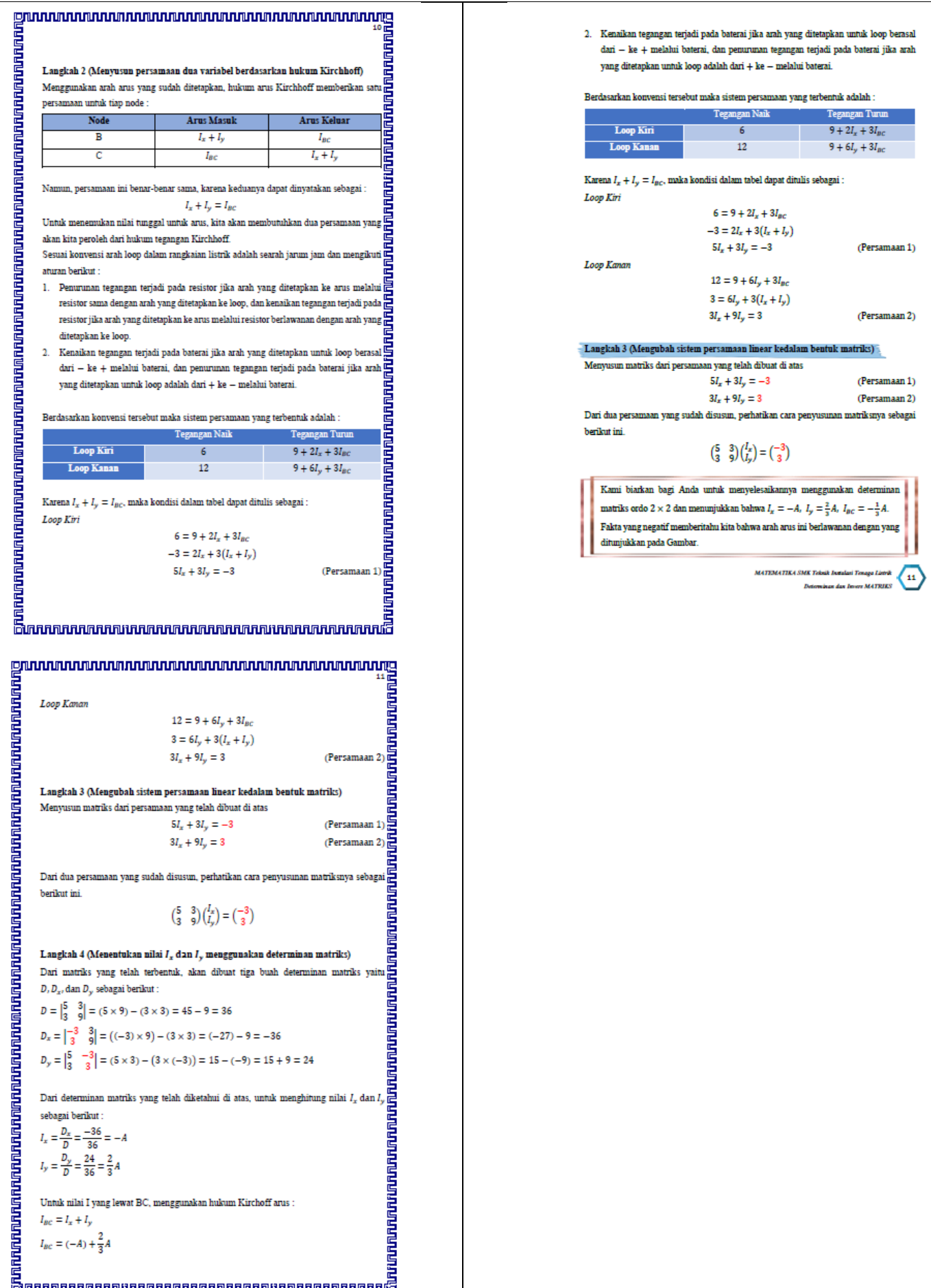

Tabel 7. Hasil Revisi Bahan Ajar dari Ahli Media

\section{Produk I Produk II (Final)}

Desain cover dapat diperbaiki menjadi lebih menarik, dapat menggunakan ilustrasi penggunaan matrik pada kehidupan nyata. Serta, penggunaan warna para cover terlalu banyak, gunakan 3 warna saja kemudian padukan. 


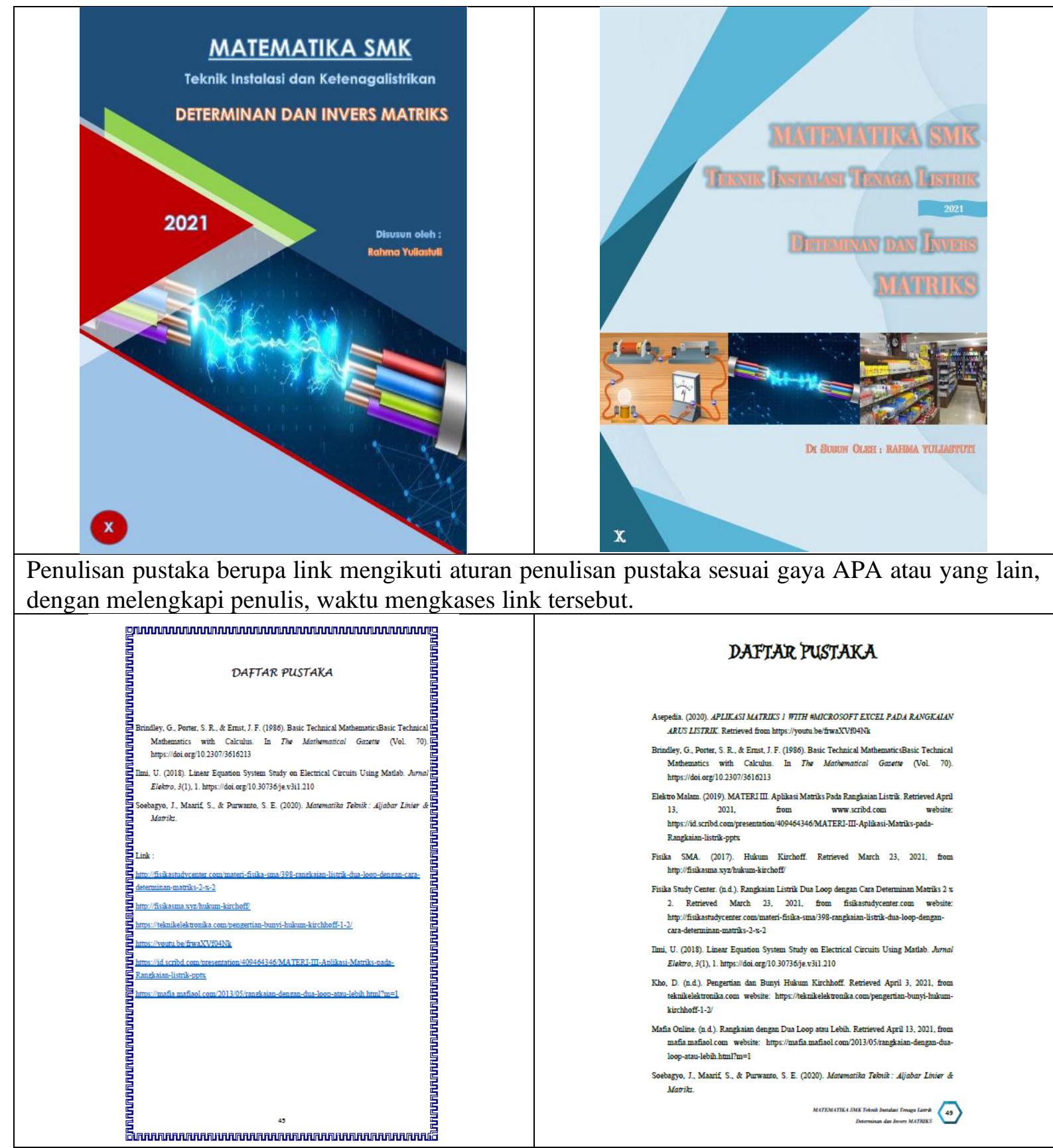

\section{Implementasi (Implementation)}

Langkah selanjutnya hasil prototipe II yang sudah diperbaiki dari prototipe I siap dilakukan ujicoba. Pada tahap ujicoba ini dilaksanakan pada guru matematika dan 18 siswa kelas X teknik listrik sebagai responden. Ujicoba memiliki tujuan untuk memperoleh data respon guru dan siswa pada bahan ajar. Penilaian kepraktisan penggunaan bahan ajar oleh guru mencakup aspek materi, penyajian, dan bahasa pada bahan ajar. Tujuannya adalah mengamati apakah bahan ajar yang dikembangkan praktis digunakan saat aktivitas pembelajaran. Berikut adalah hasil angket kepraktisan penggunaan bahan ajar oleh guru yang disajikan dalam bentuk diagram. 


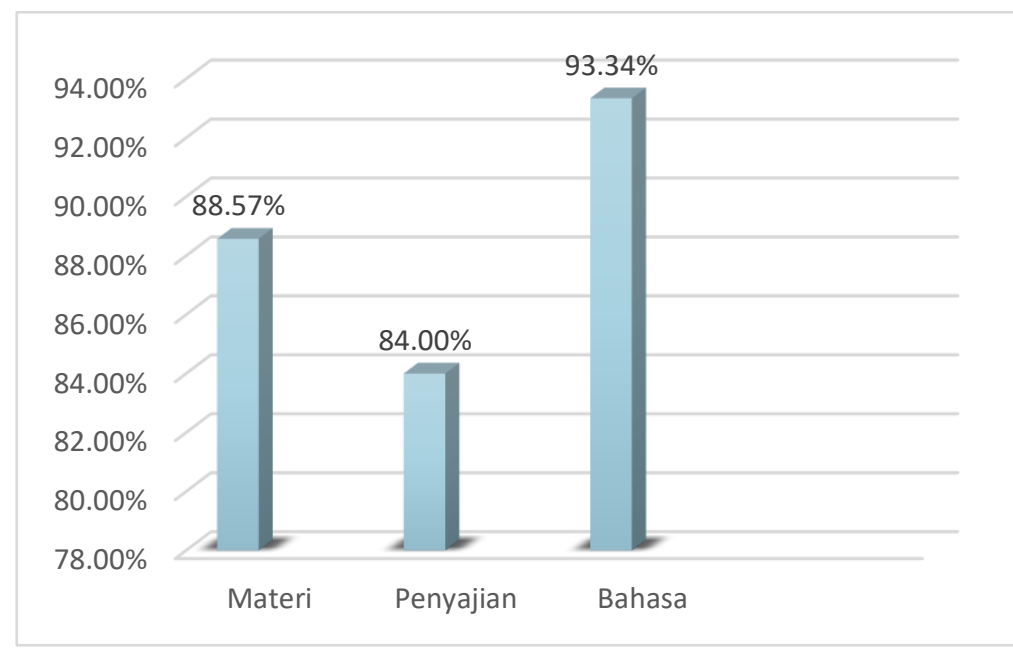

Diagram 1. Diagram Hasil Respon Guru Terhadap Bahan Ajar

Berdasarkan diagram, aspek materi pada bahan ajar adalah $88,57 \%$, aspek penyajian yaitu $84,00 \%$, dan aspek bahasa adalah 93,34\%. Rata - rata persentase dari ketiga aspek yaitu sebesar 88,64\% yang artinya respon guru terhadap bahan ajar dikatakan "Sangat Baik". Selanjutnya ujicoba pada siswa dengan menilai sesuai dengan indikator yang meliputi aspek ketertarikan, materi, dan bahasa pada bahan ajar. Berikut hasil uji coba respon siswa terhadap produk atau prototipe II bahan ajar matematika berbasis matematika terapan pada materi matriks yang disajikan dalam bentuk diagram.

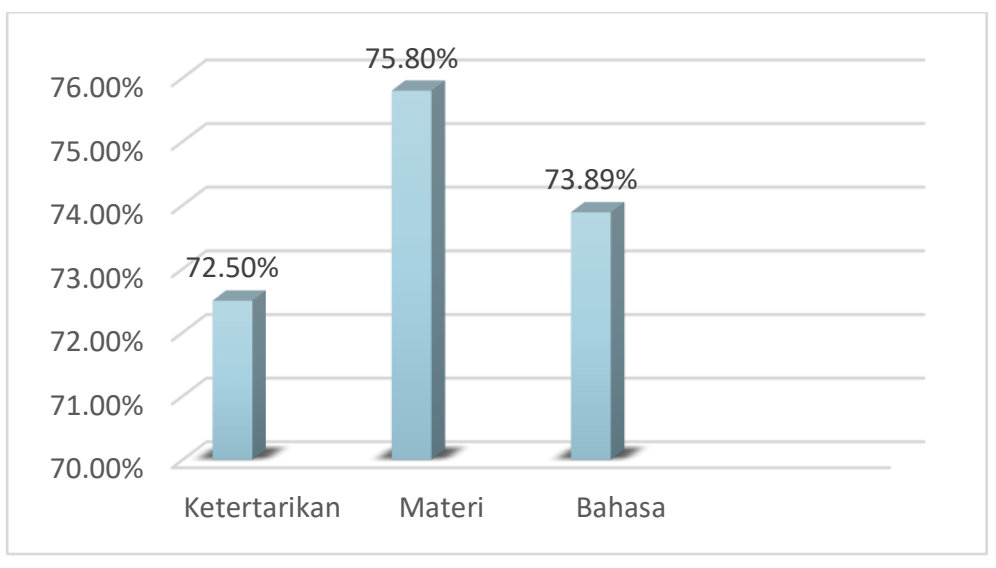

Diagram 2. Diagram Hasil Uji Coba Respon Siswa

Berdasarkan diagram, aspek ketertarikan siswa pada bahan ajar adalah 72,50\%, aspek materi pada bahan ajar adalah $75,80 \%$, dan aspek bahasa pada bahan ajar adalah 73,89\%. Rata - rata persentase dari ketiga aspek yaitu sebesar 74,06\% yang artinya hasil uji coba siswa atas bahan ajar dikatakan Baik.

\section{Evaluasi (Evaluation)}

Sesudah penilaian para ahli, produk yang dikembangkan mendapati beberapa perbaikan diantaranya desain sampul dan isi bahan ajar, langkah - langkah penyelesaian contoh soal, glosarium serta penulisan daftar pustaka. Menurut (Nieveen, 1999: 127) dalam (Chusniah \& Setianingsih, 2019), kualitas bahan ajar yang baik harus memenuhi aspek kevalidan, kepraktisan, dan keefektifan. Bahan ajar dikatakan valid, jika penilaian ahli memastikan bahwa pengembangan bahan ajar didasarkan pada teori-teori yang kuat dan memiliki konsistensi internal, yaitu ada keterkaitan antar komponen bahan ajar yang dikembangkan. Oleh 
karena itu, kriteria kevalidan dinilai dari 4 aspek kelayakan yang ditentukan oleh BSNP. Kepraktisan bahan ajar yang dikembangkan tergantung dari pendapat guru yang mengutarakan bahwa bahan ajar yang dihasilkan mudah digunakan serta sesuai dengan tujuan pembelajaran. Dalam penelitian ini, bahan ajar dikatakan praktis ditunjukkan oleh hasil angket penilaian guru. Keefektifan bahan ajar ditinjau dari kekonsistenan antar kurikulum serta pengalaman siswa. Dalam penelitian ini, keefektifan dilihat dari pengalaman siswa yang ditetapkan dengan tanggapan/respon siswa terhadap bahan ajar tersebut.

Mengikuti hasil penilaian ahli, kepraktisan bahan ajar oleh guru, juga respon siswa maka produk akhir pengembangan ialah bahan ajar matematika berbasis matematika terapan pada materi matriks untuk SMK teknik instalasi tenaga listrik dapat dikatakan mencukupi aspek kelayakan bahan ajar mencakup kriteria kevalidan, kepraktisan, dan keefektifan untuk digunakan.

Berdasarkan hasil telaah didapati penelitian yang serupa oleh Atika Nurafni dkk (Nurafni et al., 2020) yaitu Pengembangan Bahan Ajar Trigonometri Berbasis Kearifan Lokal. Tujuannya yaitu mewujudkan bahan ajar yang layak melewati pendekatan kearifan lokal pada materi trigonometri. Jenis penelitian menggunakan R\&D dengan model ADDIE. Berdasarkan temuan keseluruhan, bahan ajar dapat diterima di kalangan guru dan siswa dengan respon baik, serta didukung oleh penilaian ahli dimana menunjukkan bahan ajar layak dipakai saat pembelajaran.

\section{KESIMPULAN}

Berdasarkan hasil penelitian dan pengembangan disimpulkan bahwa penilaian hasil validasi bahan ajar para ahli memperoleh $84,12 \%$ "Sangat Layak", sehingga bahan ajar sudah dikatakan layak dan dapat diuji cobakan dengan revisi. Kemudian respon guru terhadap bahan ajar tersebut memperoleh persentase 88,64\% "Sangat Baik", dan respon siswa pada tahap ujicoba mendapat 74,06\% "Baik". Oleh sebab itu bahan ajar matematika berbasis matematika terapan pada materi matriks telah memenuhi aspek kelayakan bahan ajar mencakup kriteria validitas, kepraktisan, dan keefektifan mengikuti hasil validasi para ahli serta respon guru dan juga siswa.

Adapun saran dari hasil penelitian ini untuk peneliti selanjutnya yaitu meneliti pengaruh bahan ajar yang dibuat terhadap output belajar siswa sebelum dan setelah bahan ajar digunakan.

\section{UCAPAN TERIMA KASIH}

Saya ucapkan terima kasih kepada orang tua, keluarga dan sahabat yang senantiasa mendoakan dan memberikan dukungan. Terima kasih juga saya alokasikan kepada para dosen pendidikan matematika UHAMKA Jakarta, Kepala Sekolah dan Guru Matematika SMKN 1 Tangerang Selatan dan seluruh pihak yang turut membantu dan membimbing sehingga saya dapat menyelesaiakan penelitian dan artikel ini dengan baik.

\section{REFERENSI}

Billett, S. (2011). Vocational Education: Purposes, Traditions and Prospects [1 ed.]. In Journal of Chemical Information and Modeling (Vol. 53). https://doi.org/10.1007/978-94-007-1954-5 
Chusniah, E. R., \& Setianingsih, R. (2019). Pengembangan Komik Matematika Berbasis Kontekstual Untuk Materi Lingkaran. Jurnal Penelitian Pendidikan Matematika Dan Sains, 3(2). https://doi.org/10.26740/jppms.v3n2.p55-64

Effendi, M. M. (2017). Reposisi Pembelajaran Matematika di SMK. Prosiding Seminar Nasional Pendidikan Matematika 2017: Universitas Muhammadiyah Malang. Retrieved from http://eprints.umm.ac.id/36850/23/Effendi - Matematika SMK Reposisi Terintegrasi.pdf

Fatimah, A. T., \& Zakiah, N. E. (2018). Kelancaran Prosedural Matematis dalam Pemecahan Masalah Konteks Pemasaran. M A T H L I N E : Jurnal Matematika Dan Pendidikan Matematika, 3(2), 141150.

Fitrah, M. (2016). Model Pembelajaran Matematika Sekolah (Kajian Perspektif Berdasarkan Teori dan Hasil Riset). Yogyakarta: Deepublish.

Gallagher, J. J. (2000). Teaching for Understanding and Application of Science Knowledge. Journal of Biological Education, 100(6), 310-318.

Hasanah, H., Wirawati, S. M., \& Sari, F. A. (2020). Pengembangan Bahan Ajar Matematika Berbasis STEM Pada Materi Bangun Ruang. Indonesian Journal of Learning Education and Counseling, 3(1), 91100. https://doi.org/doi.org/10.31960/ ijolec. v3i1. 582

Hassani, S. (2009). Mathematical Methods for Students of Physics and Related Foelds. In Springer Science+Business Media.

Hine, G. S. C. (2015). Strengthening Pre-service Teachers ' Mathematical Content Knowledge. Teaching and Learning Forum, 12(4), 1-11.

Mayani, S., \& Rizki, S. (2016). Pengembangan Bahan Ajar Berbasis Pendidikan Matematika Realistik (PMR) pada Materi Program Linear. Aksioma : Jurnal Pendidikan Matematika FKIP, 5(1), 25-39.

Noer, S. H. (2018). Disain Pembelajaran Matematika. Yogyakarta: Graha Ilmu.

Nurafni, A., Pujiastuti, H., \& Mutaqin, A. (2020). Pengembangan Bahan Ajar Trigonometri Berbasis Kearifan Lokal. Journal of Medives: Journal of Mathematics Education IKIP Veteran Semarang, 4(1), 71-80. https://doi.org/https://doi.org/10.31331/medivesveteran.v4i1.978

Ojose, B. (2011). Mathematics literacy: are we able to put the mathematics we learn into everyday use? Journal of Mathematics Education, 4(1), 89-100.

Pahl, P. J., \& Damrath, R. (2001). Mathematical Foundations of ComputationaI Engineering.

Siagian, M. D. (2016). KEMAMPUAN KONEKSI MATEMATIK DALAM PEMBELAJARAN MATEMATIKA. MES (Journal of Mathematics Education and Science), 2(1).

Soebagyo, J., \& Purnama, W. (2019). Analisis Buku Aplikasi Matematika Dalam Bidang Teknik Untuk Tingkat Sekolah Menengah Kejuruan. Konferensi Nasional Pendidikan Matematika Ke-8.

Tegeh, I. M., Jampel, I. N., \& Pudjawan, K. (2014). Model Penelitian Pengembangan. Yogyakarta: Graha Ilmu. 